\title{
Recycling and Modification of Old Phones for the Old Population to Use
}

\author{
Haojun $\mathrm{Du}^{* 1}$ \\ ${ }^{1}$ Maranatha High School \\ *Corresponding author. Email: du.hank@ maranathastudents.org
}

\begin{abstract}
The increasing number of waste mobile phones is a severe problem faced by China. The rapid development of technologies, especially innovation of mobile phones, cause the continuously declined life service circle of those phones. Consequently, a large amount of waste phones need to be recycled to prevent serious environmental pollution and waste of resources. Nevertheless, considering the rapidly growing aged population in China, they have already fallen behind the pace of the time. Aged group also requires help to adapt to the new technology devices. This article primarily analyzes the current situation, barriers, and advance method of mobile phone recycling, and discusses the elders' needs and barriers of using smart phones additionally to evaluate the feasibility of building enterprises to recycle waste phones and modified them to meet the demands of the aged group. The analysis in this article reveals that both the mobile phone recycling market and the elderly consumer group have huge potential, therefore it is feasible to construct such a enterprise.
\end{abstract}

Keywords: Phones recycle and reuse, Aged society, Elder people and mobile phones, Mobile phone modification, Mobile phone recycle

\section{INTRODUCTION}

With the continuous innovation and progress of electronic technology, more and more people are starting to accept smartphones. However, behind the prosperity and rapid development of mobile phones, there are many severe potential issues that must be solved. According to He, China has been the largest mobile phone producing and consuming market since 2007 because of its large population base [3]. Since people rely more and more on smartphones, such as relaxing, paying, communicating, reading, they begin to pursue better appearance and more functions of mobile phones, which causes a severe problem: the decline of mobile phones service life cycle [2,3]. In 2015, mobile phones service life cycle is only 8 - 12 months[2].The rapid expansion of the smartphone market and the high updating rate of mobile phones leads to a tremendous amount of waste phones every year. So far, mobile phones have become one of the largest and fastest-growing waste products [2,7]. These waste phones contain many hazardous materials, if they are not disposed of or recycled properly, they will cause severe environmental pollution in China, and even threaten people's health [2]. Apart from the pollution issue, many rare resources are also contained in waste phones. Even if each phone only includes a little bit, the total amount of these rare and useful materials are incredible [1-3]. Consequently, it is of great essence to recycle these waste phones, and companies can gain benefits through this process whether they decide to extract the rare materials or resell them. Also noteworthy is that the success of this process will also promote economic growth in China. Another inevitable global trend is the ageing of the population, and this problem is particularly acute in China because of its large population base. When a country's old population(aged 65 years or more) takes over $14 \%$ of the total population, it is considered as an aged society [5]. Unfortunately, China has the largest aged population, and the ageing rate is faster than any other country. According to statistics, China will become an aged society in 2025, as a result, Yuting believes that China needs to adapt to the increasing ageing population more quickly than other countries [6]. With the rapid development of technology, the elderly are gradually falling behind the pace of The Times. Because as people get older, their pace of learning and accepting new things are far behind that of any other age groups [8]. With the coming of the ageing society, the elderly will become a new, and nearly untapped customer group. Nevertheless, the current mobile phone market continually develops more complex functions to satisfy the young's demand regardless of the thoughts of the elder group, which causes barriers for elders. This article mainly talks about the feasibility of building enterprises in china to recycle mobile phones and modify them in order to resell to the aged group to meet their demand. The article will discuss respectively the market prospect of recycling old mobile phones, and how to modify mobile phones to meet the demand of the 
elders. All data in this article is based on secondary research.

\section{MARKET PROSPECT OF RECYCLING OLD MOBILE PHONES}

\subsection{The Current Situation of Old Phones Recycling}

In order to investigate the phone recycling market, the first step is to research people's attitude towards old phones recycling and find out what they currently do with their old phones. Since teenagers are still the largest smartphone consumer group right now, we can understand the whole consumer group through their attitude and treatment methods. According to Maria, $90.1 \%$ of German teenagers have at least one or more mobile phones which are not used regularly [4]. Here an interview sample survey from Maria Jolanta Welfens based on teenagers aged 9 to 18 in Germany is applied (see table 1\&2).

Table 1. Sample survey about still working mobile phones [4]

Table 1. What do you do with your old mobile phone if it is still working? (multiple answers possible, total number of answers $=1306$, in $\%, n=717$ ).

\begin{tabular}{ccc}
\hline Number/answer & Options/usage/ & Frequencies \\
\hline 1 & Sell & $23.6 \%$ \\
2 & Used by another family member & $58.6 \%$ \\
3 & Give it away & $6.6 \%$ \\
4 & Keep it as second mobile & $48.1 \%$ \\
5 & Household waste & $1.4 \%$ \\
6 & Return it to mobile phone shop & $2.8 \%$ \\
7 & Mobile phone collection box & $3.2 \%$ \\
8 & Return to (charity) organisation & $1.5 \%$ \\
9 & Yellow bin for electronic waste & $1.1 \%$ \\
11 & Recycling bag of mobile phone provider & $0.4 \%$ \\
12 & I didn't know where to return is, therefore I kept it & $11.2 \%$ \\
13 & I have never given thought to returning it, therefore I kept it & $18.1 \%$ \\
14 & Other & $1.7 \%$ \\
\hline
\end{tabular}

Table 2. Sample survey about broken mobile phones [4]

Table 2. What do you do with your old mobile phone if it is broken? (multiple answers possible, total number of answers $=790$, in $\%, n=717$ ).

\begin{tabular}{ccc}
\hline Number/answer & Options/usage & Frequencies \\
\hline 1 & I sell it to someone doing handicraft work & $8.2 \%$ \\
2 & I keep it & $54.8 \%$ \\
3 & I throw it away & $11.6 \%$ \\
4 & I return it to the shop when buying a new one & $11.3 \%$ \\
5 & I bring it to a mobile phone collection box & $8.5 \%$ \\
6 & Other & $8.8 \%$ \\
7 & n.a. & $7.0 \%$ \\
\hline
\end{tabular}

717 randomly chosen teenagers were required to answer separately what they would do with their old and broken phones. When mobile phones are still working, most teenagers will try to extend mobile phones life cycle by keeping it as an alternative $(48.1 \%)$ or giving it to family members or friends(58.6), a quarter of them consider about resell the to others $(23.6 \%)$, and more importantly, $11.2 \%$ teenagers don't know how to return mobile phones and $18.1 \%$ of them even never thinking about recycling old phones. Besides, only $7.5 \%$ of teenagers return and recycle their old mobile phones, that is a really small number. When it comes to treatments of broken phones, still more than half of teenagers decide to keep them(54.8\%), and only $19.5 \%$ of them decide to return broken phones to the shop or collection box. It seems that a larger percentage of people decide to return or recycle their broken mobile phones, however, $19.5 \%$ is still a small number. Here is the graph about how Chinese people deal with their old mobile phones (figure 1). 


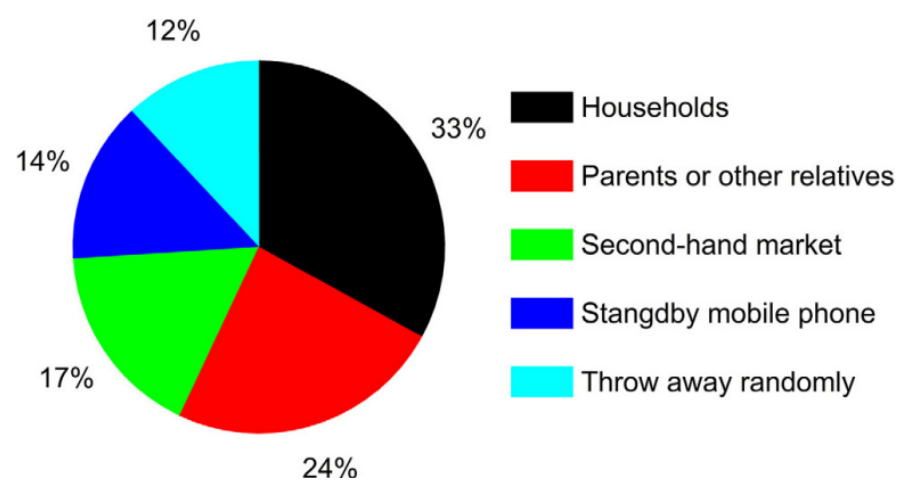

Figure 1 Directions of waste mobile phones in China [9]

It is obvious that Chinese consumers do not even take recycling old phones into consideration, they are more likely to keep them as alternatives(14\%) or give them to others $(24 \%), 33 \%$ of old phones are left unused at home, and $17 \%$ will be resold in the second-hand market. Based on table 1 and figure 1 , it is noticeable that only a small percentage of old mobile phones are properly recycled. Assumption that all the waste phones are recycled, the enterprise can gain amazing profit through them. Consequently, it is valid that the mobile phone recycling market has huge potential.

\subsection{Barriers of Old Phones Recycling}

Although the recycling market's prospect is attractive, phone recycling still faces many challenges and barriers. Based on Maria's perspective, barriers can be separated into two series, internal and external [1]. Internal barriers are how people's thoughts influence their decision. Basically, there are two major internal barriers. The first one is easily figured out through the table and figure above (figure 1), it seems that most people do not have the awareness of environmental protection and they do not know the importance of phone recycling. Moreover, personal interests are also a very important issue. Recycling mobile phones may cost people's time to look for recycling places and bring few profits to them. So the second internal barrier is that they may not be willing to recycle their phones because they cannot gain enough benefits through this process. It is also worth noting that recycling mobile phones is not only the responsibility of consumers, but also the responsibility of producers and the government, so external factors need to be taken into account. If the manufacturers or the government cannot provide efficient welfare policies, consumers will lack the motivation to recycle mobile phones; If society lacks facilities for efficient recycling methods, consumers may cannot recycle even if they are willing to. These hurdles must be overcome if an enterprise wants to enter the market for recycled phones and profit from it.

\subsection{Existing Measures and Improvement Strategies for Waste Mobile Phones Recycling}

Before China realizes the necessity of recycling old mobile phones, most of those waste phones would not be recycled systematically, but mainly through three other ways [3].

Many old phones (17\%) that are still working go into the secondary market and are refurbished, sold as second phones at a cheaper price, often without a guarantee of quality

Some waste phones which are broken (12\%) will be thrown away and be treated as normal life garbage. Nonetheless, phones are electronic waste, and they contain many harmful materials(such as the battery). If they are not dealt with properly, they will produce great harm to the environment. Moreover, those rare materials in waste phones cannot be extracted as well.

Some individuals or small companies will recycle some waste mobile phones because of the huge profit. They will buy waste mobile phones house by house at a relatively low price, and then disassemble those phones to recycle precious metals. However, due to the immature technology, their recycling methods often cause secondary pollution to the environment. For instance, They often use combustion or sulfuric acid to extract rare metals, which will produce harmful gases and pollute the environment [3].

It is not until recent years that Chinese government gradually pays attention to this problem, and mobile phone manufacturers such as Huawei also start to offer benefits through online and physical stores to encourage people to recycle. So what is a really efficient campaign for old phones recycling? The table below (table 3) based on the norm activation model and scientific research from Maria provides some useful suggestions. 
Table 3. Criteria for successful communication and collection campaigns derived from the norm activation model and empirical research [1]

\begin{tabular}{|c|c|c|c|c|}
\hline \multicolumn{2}{|c|}{ Criterion } & Description & $\begin{array}{l}\text { Theory: } \\
\text { Norm activation model }\end{array}$ & $\begin{array}{l}\text { Empirical research project: } \\
\text { "Return and use of old mobile } \\
\text { phones" }\end{array}$ \\
\hline 1 & Clear message & $\begin{array}{l}\text { A clear message that enables } \\
\text { addressees to understand the } \\
\text { (sustainability) problem } \\
\text { communicated by the campaign } \\
\text { as well as the relationship } \\
\text { between individual behaviour and } \\
\text { the respective problem }\end{array}$ & $\begin{array}{l}\text { Raising awareness of the } \\
\text { problem; providing knowledge } \\
\text { and understanding of the } \\
\text { connection between one's } \\
\text { individual behaviour and the } \\
\text { sustainability problem; providing } \\
\text { knowledge on what to do (clear } \\
\text { instructions), part of the } \\
\text { "activation of norms" phase. }\end{array}$ & $\begin{array}{l}\text { Providing knowledge about the } \\
\text { relevance of recycling mobile } \\
\text { phones can be a motivational } \\
\text { factor for recycling practices. } \\
\text { Clear instructions support broad } \\
\text { participation in communication } \\
\text { and collection campaigns }\end{array}$ \\
\hline 2 & $\begin{array}{l}\text { Educational } \\
\text { elements }\end{array}$ & $\begin{array}{l}\text { Supporting educational measures } \\
\text { to raise addressees' awareness } \\
\text { of the campaign (id est } \\
\text { customers) } \\
\text { Accompanying educational } \\
\text { measures to raise the awareness } \\
\text { of members of staff who are in } \\
\text { direct contact with customers }\end{array}$ & $\begin{array}{l}\text { Intervention at the "activation } \\
\text { of norms" phase. }\end{array}$ & $\begin{array}{l}\text { (Target group-oriented) } \\
\text { education and communication } \\
\text { material is important for } \\
\text { developing an individual } \\
\text { "resource-saving habit" }\end{array}$ \\
\hline 3 & $\begin{array}{l}\text { Access to } \\
\text { infrastructures }\end{array}$ & $\begin{array}{l}\text { Easy access to return } \\
\text { infrastructures }\end{array}$ & $\begin{array}{l}\text { This section focuses on the } \\
\text { motivation phase: the cost of } \\
\text { behaviour should be kept low. }\end{array}$ & \\
\hline 4 & $\begin{array}{l}\text { Information about } \\
\text { participation via } \\
\text { communication } \\
\text { channels }\end{array}$ & $\begin{array}{l}\text { Broad dissemination of } \\
\text { information about the opportunity } \\
\text { to participate in the campaign }\end{array}$ & "Activation of norms" phase. & \\
\hline 5 & $\begin{array}{l}\text { Economic } \\
\text { incentives }\end{array}$ & $\begin{array}{l}\text { Economic incentives in order to } \\
\text { motivate people to participate }\end{array}$ & $\begin{array}{l}\text { Economic incentives influence } \\
\text { the motivation phase }\end{array}$ & $\begin{array}{l}\text { Economic incentives are a } \\
\text { strong factor that influence } \\
\text { people's willingness to } \\
\text { participate in campaigns }\end{array}$ \\
\hline
\end{tabular}

The table provides a general idea of what an enterprise needs to do to resolve all the barriers mentioned above and recycle in a highly efficient way. Based on table 3 and the market situation in China, the following are four main steps of improvement strategy of phone recycling.

Primarily, enterprises must raise people's awareness of recycling. Enterprises need to popularize the knowledge of environmental protection and sustainable development to the public, raise their awareness of environmental protection and let them understand the importance of recycling used mobile phones. They can achieve their goals through making promotional videos and posting on the internet (Youtube or Tik Tok) or making public speeches to appeal to people. Cooperation with the government will be the best choice. With the support of the government, enterprises may be allowed to popularize environmental protection knowledge on campus, or they can put posters in crowded places such as transportation hubs to raise the awareness of the public.

The second step belongs to the government, it should enact laws to ban irregular recycling methods in order to avoid the second pollution and encourage enterprises to recycle waste phones.
For people's convenience of phone recycling, enterprises should build more infrastructures such as recycling sites. Therefore people may get easier access to infrastructure and save their time. However, enterprises also need to keep their costs affordable while reducing people's time cost to ensure their profit, so probably collection boxes or special trash cans for waste mobile phones will be a good solution.

Enterprises also need to create plans to provide benefits or economic incentives to people so as to motivate people to recycle their waste mobile phones. Huawei is a great example, they have launched the old for new service program since 2015 as an incentive for people to recycle old phones [18]. In case that there are no economic incentives provided, people would not be willing to recycle their phones even though they have the awareness of environmental protection, because this behavior will not bring them personal benefit. 


\section{MEET ELDERS' NEEDS THROUGH MODIFYING OLD PHONES}

\subsection{Reasons of Using Phones}

Jenna's collected data shows that there are $0 \%$ people aged over 70 who owned smartphones in 2005 , but the percentage grew from 0 to 31.3 in 2012 [12]. So what are the factors which motivate them to use smartphones? The reason can be categorized into 4 groups.

Communication is always the primary function of a phone, especially for the elders. Usually older people will become more sensitive, they crave the company of family members or friends more than any other age group. However, sometimes the elders' family members may become busy at work and ignore their mental condition, and they may come up with the feeling of loneliness and isolation. Luckily, mobile phones solve the problem perfectly. Through video calls, elder people can contact their children or friends even if they are thousands of miles away. Since both of their faces are shown on the screen, they can feel each others' emotions, just like talking face to face.

Recreation function is also of great importance to the aged group. Many people associate entertainment with young people, but older people also need leisure. They can play some developmental games to practice their thinking ability and improve their memory. This may prevent them from getting cognitive issues such as Alzheimer's disease. smartphones are also applied by older people as an alternative to TV or newspaper, they tend to watch news or recreation videos through phones to relieve feelings of loneliness.

Security is also a factor that promotes elders to use smartphones. Many old people mention that they will achieve a sense of safety when they have phones with them. That is because smartphones allow them to be reachable at any time, they can call their family members to chat with them in order to release their pressure when they feel flustered or frightened. For example, some elder people with memory issues may lose their ways when they are outside, they may feel alarmed and perplexed. But because they have smartphones with them, they can call the police or others for help. Furthermore, most smartphones have developed the function of GPS positioning, this function will benefit elder people's family members since they can find those elders easily.

Another strong factor that inspires the elder groups to use mobile phones is the ability to cope with daily lives. With the rapid development of technologies, mobile phones have formed a close bond with all aspects of people's daily lives in China, especially in large cities. People use their phones to take taxis, pay, order take-out, do online shopping and etc. it seems like people cannot do many things without their mobile phones. During the covid-19 pandemic, people in China are required to show their security code to go outside. Consequently, everyone, including the old people, was forced to register a security code on their phones. In fact, the elders living in modern cities are forced to use smartphones, otherwise they cannot cope with their daily lives.

\subsection{Barriers of Using Smartphones}

Functional capacity refers to people's ability to understand and master how to use a device [13], this plays an important role in old people's attitude toward smartphones. Undeniably, functional capacity will decline as people age. As a result, they may not be willing to accept smartphones since it will take them a long time to adapt and learn how to use them. In recent years, mobile phone producers are still researching and developing more functions of smartphones to fit the needs of young customers. The increasing complexity of mobile phones may make it harder for elders to adapt to them. Moreover, people often feel anxiety and panic about unknown things, elder people may worry about accidentally breaking their phones. Providing that an old man's children bought a new smartphone for him, but he never used that before and touched the power off button by mistake, and the phone will shut down. He might think he broke the phone and feel frustrated. Even if someone told him later that everything is fine with the phone, the old man may still avoid using it since he does not want to break it.

People's memory will decline as they getting older, some of them may become very forgetful. Unlike young people, many old people are not in the habit of carrying mobile phones with them, hence mobile phones loss will be a common problem. They may drop their phone anywhere and only remember it when they need it, but that is too late, it is nearly impossible for them to find their phones if they leave their phones outside such as in shopping malls or parks. Charging will also be a problem for them, since they may forget to charge their phones or cannot find their phone chargers.

Many old people are suffering from health issues as well, such as vision diminution and hearing disorder. The character size and volume size of mobile phones may meet the requirement of most customers, but it will bring troubles to the elder customer segment, they may require a larger size of characters to read clearly and a larger volume to catch their attention when someone calls them. Many elderly Chinese people will wear reading glasses when they check their phones, which is really inconvenient.

Considering the factors of culture and ideology, they will also influence old people's opinions toward the adaptation of smartphones. In China, the elders tend to 
be more likely to save their money for their offspring since neither Taoism nor Buddhism encourages people to improve their life quality. Consequently, many of them may not be willing to buy smartphones because of the expensive price. Their ideas are usually stubborn and hard to persuade.

\subsection{Suggestions for Modification and Sales of Recycled Phones}

Considering the elders' declined functional capacity, enterprises should delete unhelpful Apps for them, otherwise it will be too complex for them to understand. Therefore, only a small portion of them will be kept except for basic function. Besides, some recreation apps also are expected to be designed particularly for the aged group to fit their entertainment demands. Additionally, the process of operating the phone will be simplified, and the names of all apps and functions will be as clear and transparent as possible, in case older people don't understand them.

With regard to old people's memory and health issues, the cases of old phones will be changed to a more conspicuous color to attract owners' attention, which helps to prevent phone loss. GPS positioning system will be installed, Once an elder loses his cell phone, the location of the phone will be sent to his families. Besides, both the sizes of character and volume will be magnified for the sake of the elder group's convenience. When there is a call, the phone will ring, vibrate and light up the screen at the same time to draw the elder's attention, which ensures them to receive the call.

The price of these phones will be low since they are recycled old phones, but the elders will not be the largest target customers of the enterprises because it is hard to change the elders' opinion in a short time. If people are not aware of their own needs for a product, they will never buy it, the elderly are no exception. If the elders never used phones before, they may think it is not necessary to waste money on that. Consequently, the largest customer group is always their family members, who will buy phones for the elders, so the sales strategy of the enterprise should not only pay attention to the elderly, but also their family members.

\section{CONCLUSION}

The data analysis of the waste phone recycling market in China demonstrates that there is still not a well-established recycling process. People lack the awareness of environmental protection and don't know the importance of phone recycling. Few recycling infrastructures and economic incentives are constructed by the government and producers. Therefore, a large number of waste phones are not recycled properly, which may cause serious environmental pollution and waste of rare resources. In order to solve these barriers, the government is expected to popularize the need for mobile phone recycling in public places or online to raise people's awareness, and also make some regulations to provide more financial benefit for people to motivate them to recycle their old phones. In addition, more infrastructures such as phone recycle boxes should be constructed to save people's time. Overall, the waste phone recycling market in China is of great potential. Enterprises need to actively cooperate with the government to recycle old phones since broken phones can be recycled to extract rare materials, and still working old phones can be modified and reused.

In recent years, the demand for mobile phones among the aged group also increased dramatically. Consequently, a large portion of the still working mobile phones can be modified and sell in the aged group. However, unlike normal phones, modified mobile phones need to contain the following features to better satisfy the need to the elderly. Initially, the manipulating process will be simplified and useless apps will be deleted according to elder's declined functional capacity, and some recreation functions will be added to help them to relax and release sense of loneliness. Additionally, the appearance of mobile phones will become more colorful to prevent phone lost, and both the volume and the font will be magnified due to the fading ability of hearing and vision in the elderly. Despite the price of recycled mobile phones will be kept at a low level, it is noteworthy that many of the elders may not willing to buy the modified mobile phones, thus their family members or friends may be the main consumer group.

\section{ACKNWLEDGMENT}

First and foremost, I would like to show my deepest gratitude to my teachers and professors in my university,who have provided me with valuable guidance in every stage of the writing of this thesis. Further,I would like to thank all my friends and roommates for their encouragement and support. Without all their enlightening

instruction and impressive kindness, I could not have completed this paper.

\section{REFERENCES}

[1] Welfens, M. J., Nordmann, J., \& Seibt, A. (2016). Drivers and barriers to return and recycling of mobile phones. Case studies of communication and collection campaigns. Journal of cleaner production, 132, pp.108-121.

[2] Xu, C., Zhang, W., He, W., Li, G., \& Huang, J. (2016). The situation of waste mobile phone management in developed countries and 
development status in China. Waste Management, 58, pp. 341-347.

[3] He Y., \& Li L. (2007). A Study on Recovery and Recycle of Old Mobile Phones in China. In The second national academic conference on solid waste treatment technology and engineering design, China Urban Environmental Sanitation Association. pp. 91-94.

[4] Welfens, M. J., Nordmann, J., Seibt, A., \& Schmitt, M. (2013). Acceptance of mobile phone return programmes for increased resource efficiency by young people-experiences from a German research project. Resources, 2(3), pp.385-405.

[5] Chen, R., Xu, P., Song, P., Wang, M., \& He, J. (2019). China has faster pace than Japan in population aging in next 25 years. Bioscience trends, 13(4), pp.287-291.

[6] Han, Y., He, Y., Lyu, J., Yu, C., Bian, M., \& Lee, L. (2020).Aging in China: perspectives on public health. Global Health Journal, 4(1), pp.11-17.

[7] Sarath, P., Bonda, S., Mohanty, S., Nayak, S.K., (2015). Mobile phone waste management and recycling: views and trends. Waste Manage. 46, pp.536-545.

[8] Barnard, Y., Bradley, M. D., Hodgson, F., \& Lloyd, A. D. (2013). Learning to use new technologies by older adults: Perceived difficulties, experimentation behaviour and usability. Computers in human behavior, 29(4), pp.1715-1724.

[9] NetEase Technology. (2015). Where did Discarded Phones Go in China?[Online] <http://tech163.com/photoview/0AI20009/8360.ht $\mathrm{ml} \# \mathrm{p}=\mathrm{B} 8 \mathrm{~K} 1 \mathrm{JUP} 10 \mathrm{AI} 20009>$;

[10] Kathleen, Schreurs, Anabel, Quan-Haase, Kim, \& Martin. (2017). Problematizing the digital literacy paradox in the context of older adults' ict use: aging, media discourse, and self-determination. Canadian journal of communication, 42(2), pp.359-377.

[11] Hasegawa, S., Matsunuma, S., Omori, M., \& Miyao, M. (2006). Aging effects on the visibility of graphic text on mobile phones. Gerontechnology, 4(4), pp.200-208.

[12] Jacobson, J., Lin, C. Z., \& McEwen, R. (2017). Aging with technology: Seniors and mobile connections. Canadian Journal of Communication, 42(2), pp.331-357.

[13] Ziefle, M., \& Bay, S. (2005). How older adults meet complexity: aging effects on the usability of different mobile phones. Behaviour \& information technology, 24(5), pp.375-389.

[14] Plaza, I., Martín, L., Martin, S., \& Medrano, C. (2011). Mobile applications in an aging society: Status and trends. Journal of Systems and Software, 84(11), pp.1977-1988.

[15] Navabi, N., Ghaffari, F., \& Jannat-Alipoor, Z. (2016). Older adults' attitudes and barriers toward the use of mobile phones. Clinical interventions in aging, 11, pp.1371-1378.

[16] Lin, C. J., Hsieh, T. L., \& Shiang, W. J. (2009). Exploring the interface design of mobile phone for the elderly. In International Conference on Human Centered Design , 5916, pp. 476-481.

[17] Mallenius, S., Rossi, M., \& Tuunainen, V. K. (2007). Factors affecting the adoption and use of mobile devices and services by elderly people-results from a pilot study. 6th Annual Global Mobility Roundtable, 31, pp.1-12.

[18] HUAWEI, 2015. HUAWEI “Green Action 2.0”: Old for New Service, Build a Positive Recovery Model of Mobile Phones $<$ http://consumer.huawei.com/cn/press/news/hw-45 0792.htm> 